\title{
Negasi Verba Dialek Osaka Dalam Novel Hibana Karya Matayoshi Naoki
}

\author{
Putu Yuhi Ikeda $^{1}$, Ni Putu Luhur Wedayanti ${ }^{2)}$ \\ ${ }^{[1,2]}$ Program Studi Sastra Jepang, Fakultas Ilmu Budaya \\ Denpasar Bali

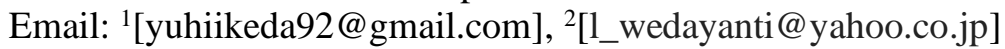

\begin{abstract}
Abstrak
Penelitian ini bertujuan untuk mengetahui pembentukan negasi verba serta makna tuturan yang menggunakan negasi verba dialek Osaka dalam novel Hibana karya Matayoshi Naoki. Penelitian ini menggunakan teori morfologi menurut Tsujimura dan teori tindak tutur ilokusi menurut Searle. Pada tahap pengumpulan data digunakan metode simak yaitu dengan menyimak tuturan dalam novel. Kemudian data yang diperoleh dilanjutkan dengan teknik catat. Metode yang digunakan pada analisis data yaitu metode agih serta dalam penyajian hasil analisis data digunakan metode informal. Berdasarkan hasil analisis dalam novel Hibana ditemukan enam data yang mengandung unsur negasi verba hen dan empat data yang mengandung unsur negasi verba hin. negasi verba yang diikuti oleh sufiks hen dibentuk sesuai dengan jenis kosakata kerja dalam bahasa Jepang yaitu godandoushi dan ichidan doushi. Ichidandoushi dibagi menjadi dua yaitu kami ichidan doushi yang merupakan kata kerja berakhiran iru, serta shimo ichidan doushi yang merupakan kata kerja berakhiran suara $\sim$ eru. Pada pola negasi verba $\sim$ hen hanya dapat digunakan untuk shimo ichidan doushi saja. sedangkan untuk pola negasi verba hin hanya dapat digunakan untuk kami ichidan doushi saja. selanjutnya ditemukan 13 bentuk tindak tutur ilokusi yang menggunakan negasi verba dialek Osaka yang digolongkan ke dalam tiga data yang mengandung unsur tindak tutur asertif, dua data yang mengandung unsur tindak tutur direktif, dan delapan data yang mengandung unsur tindak tutur ekspresif.
\end{abstract}

Kata Kunci : Negasi verba, dialek Osaka, tindak tutur ilokusi

\begin{abstract}
This research aims to determine the formation of verb negation and illocutionary speech acts using the Osaka dialect verb negation found in the novel Hibana by Matayoshi Naoki. This research uses morphological theory according to Tsujimura (1999) and illocutionary speech act theory according to Searle (2006). The data collection method used in this research is the observation method, namely by listening to the utterances in comics. Then the data obtained was followed by a note-taking technique. The method used in data analysis was the agih method. Furthermore an informal method is used in presenting the results of the data analysis. Based on the analysis results found six data containing the negation element of the -hen verb and four data containing the element of negation of the verb -hin, the negation of the verb followed by the suffix -hen is formed according to the type of vocabulary. in Japanese, namely godandoushi and ichidan doushi. Ichidandoushi is divided into two, namely kami ichidan doushi which is a verb ending in -iru, and shimo ichidan doushi which is a verb ending in the sound -eru In the verb negation pattern -hen verb only be used for shimo ichidan doushi, -hin can only be used for kami ichidan doushi only, then it is found 13 forms of illocutionary speech acts that use the negation of the Osaka dialect verb which is classified into three data containing elements of assertive speech acts, two data containing elements of directive speech acts, and eight data containing elements of expressive speech acts.
\end{abstract}

Keywords: Verb Negation, Osaka dialect, illocutionary speech act. 


\section{Pendahuluan}

Osaka merupakan salah satu daerah di Jepang yang penggunaan dialek dalam masyarakatnya memiliki ciri khas yang membedakannya dengan bahasa Jepang pada umumnya. Dialek Osaka adalah salah satu dari beberapa dialek yang ada di Jepang. Dialek yang diklasifikasikan menurut prefektur disebut dengan -ben, sehingga sebutan dialek Osaka adalah Osaka-ben, dialek Nagoya adalah Nagoya-ben dan seterusnya. (Tanaka, dalam Sudjianto 2007:11). Chaer (2004:61) menyatakan bahwa dialek merupakan variasi bahasa suatu daerah yang membedakannya dengan daerah lain. Variasi bahasa ini kerap digunakan sebagai alat ekspresi diri sekaligus alat untuk menunjukkan identitas diri. Dalam bahasa Jepang dialek disebut dengan hougen.

Setiap bahasa tentunya memiliki bentuk penyangkalan atau yang sering disebut dengan negasi. Negasi merupakan penyangkalan, peniadaan, atau kata sangkal (Alwi 2005:77). Negasi dalam istilah bahasa Jepang disebut dengan istilah hiteikei atau disebut juga dengan uchikeshi. Bentuk negasi ada bermacam-macam tergantung dari kata yang diikuti dan kata yang mengikutinya. Adapun kata-kata yang bisa mengikuti ataupun diikuti bentuk negasi adalah kata benda, kata kerja, dan kata sifat.

Pembentukan kata dalam bahasa Jepang menurut Tsujimura dapat diklasifikasikan menjadi lima proses (dalam Wedayanti,2015) Sebagai bahasa aglutinatif, Bahasa Jepang banyak memiliki kata majemuk yang mengalami proses afiksasi (Wedayanti, 2016). Pembentukan negasi dapat dikategorikan sebagai proses afiksasi dalam pembentukan kata tersebut. Selain pembentukan negasi verba dialek Osaka, penelitian ini juga membahas mengenai tindak tutur ilokusi yang menggunakan negasi verba pada novel Hibana karya Matayoshi Naoki. Austin (dalam Fujibayashi 2001:5) menyebutkan tindak tutur ilokusi merupakan tindak tutur yang bila penutur mengatakan X maka ia menegaskan Y. Dapat dipahami bahwa melalui tindak tutur dapat terjadi tindakan yang mengandung fungsi terima kasih, permintaan, pelaporan, perjanjian, pertanyaan, pemberkatan, perintah, dan lain sebagainya.

Berdasarkan latar belakang yang telah diuraikan, maka dapat dirumuskan permasalahan sebagai berikut:

1. Bagaimanakah pembentukan negasi verba dialek Osaka yang terdapat pada novel Hibana karya Matayoshi Naoki? 
2. Bagaimanakah makna tuturan yang mengandung negasi verba dialek Osaka yang terdapat pada novel Hibana karya Matayoshi Naoki?

Penelitian ini bertujuan untuk menambah penelitian yang memiliki keterkaitan dengan dialek dan berharap adanya peningkatan ketertarikan masyarakat terhadap dialek Osaka. Secara khusus penelitian ini bertujuan untuk mengetahui untuk mengetahui pembentukan negasi verba serta tindak tutur ilokusi yang menggunakan negasi verba dialek Osaka yang terdapat dalam novel Hibana karya Matayoshi Naoki.

\section{Metode dan Teori}

\subsection{Metode Penelitian}

Metode pengumpulan data dalam penelitian ini adalah metode simak dan teknik catat. Metode agih digunakan pada tahap analisis data dan metode informal yang digunakan pada tahap hasil analisis data. Teori yang digunakan yaitu pertama, teori morfologi oleh Tsujimura (1999) untuk menganalisis pembentukan negasi verba yang terdapat pada kalimat tuturan dialek Osaka. Kedua, teori tindak tutur ilokusi oleh Searle (2006) untuk menganalisis makna tuturan yang mengandung dialek Osaka.

\subsection{Teori}

\subsubsection{Morfologi}

Istilah morfologi dalam bahasa Jepang disebut keitairon ( 形 態 論 ). Keitairon merupakan cabang linguistik yang mengkaji tentang kata dan proses pembentukannya. Menurut Tsujimura (1999:148), ada lima pembentukan kata dalam bahasa Jepang yaitu afiksasi, komposisi, reduplikasi, kliping, borrowing.

\subsubsection{Tindak Tutur Ilokusi}

Tindak tutur ilokusi yaitu tindak tutur yang akan menimbulkan fungsi tindakan pertanyaan, permintaan, perintah, perjanjian, sumpah, peringatan, pengumuman, conventional force atau dengan kata lain sebuah tindakan yang terjadi pada sebuah tuturan. Searle (dalam Yamaoka, 2006: 140) mengklasifikasi tindak tutur ilokusi menjadi lima jenis yaitu assertives (tindak tutur asertif), directives (tindak tutur direktif), commissives (tindak tutur komisif), declarations (tindak tutur deklarasi), expressives (tindak tutur ekpresif). 


\section{Kajian Pustaka}

Kajian pustaka dilakukan untuk mencari referensi terhadap penelitian yang dilakukan. Berdasarkan data-data yang telah dikumpulkan, terdapat beberapa penelitian yang relevan untuk dijadikan sebagai acuan terhadap penelitian ini. Adapun penelitian-penelitian tersebut adalah sebagai berikut:

Rohmah (2017) dalam skripsinya yang berjudul "Analisis Tindak Tutur Dalam Komik Tokyo Ghoul: re Karya Ishida Sui" membahas tindak tutur perlokusi dan jenis tindak tutur ilokusi dalam komik Tokyo Ghoul: re. Teori yang digunakan adalah Tindak Tutur Ilokusi Searle (2009) dan Verba Perlokusi Alston (1990). Hasil penelitiannya menunjukkan bahwa ditemukan 86 data mencakup 65 jenis tindak tutur ilokusi menurut Searle (2009) dan 21 verba perlokusi menurut Alston (1990). Jenis tindak tutur ilokusi yang ditemukan yaitu tindak tutur ilokusi asertif, ilokusi direkif, ilokusi komisif, dan ilokusi ekspresif, sedangkan verba perlokusi yang dominan pada komik "Tokyo Ghoul:re" adalah efek yang termasuk kategori verba mengganggu.

Nurhasanah (2012) dalam penelitiannya yang berjudul "Analisis Settougo Fu-, Mu-, Hi-, dan Mi- Dalam Bahasa Jepang" membahas tentang pendeskripsian makna settougo fu-, mu-, hi-, dan mi-, serta penggunaannya dalam bahasa Jepang. Teori yang digunakan adalah teori Morfologi Ba'dulu (2005). Penelitian ini menunjukkan bahwa settougo fu-, mu-, hi-, dan mi- menyatakan makna negasi, akan tetapi masing-masing settougo memiliki makna dan penggunaan yang berbeda. Dalam penggunaannya terdapat beberapa settougo fu-, mu-, hi-, dan mi- yang saling menggantikan, akan tetapi jumlahnya sangat terbatas dan hubungan saling menggantikan ini tergantung pada konteks kalimatnya.

Purba (2008) dalam skripsinya yang berjudul “Analisis Bentuk Negasi -nu,- zu (-ni), dan mai dalam Kalimat Bahasa Jepang (kajian morfosintaksis dan semantik)" membahas tentang analisis bentuk negasi -nu, -zu(ni)、 dan -mai dalam kalimat bahasa Jepang yang dikelompokkan kedalam penggunaannya dalam

kalimat serta maknanya. Teori yang digunakan adalah teori morfosintaksis dari Crystal (1980) dan teori semantik dari Chaer (2009). Hasil penelitiannya menunjukkan bahwa terdapat 50 bentuk negasi dalam kalimat bahasa Jepang yang disebut dengan hiteikei atau bisa juga disebut uchikeshi (penyangkalan) yang diklasifikasikan ke dalam 3 kelompok. Pengklasifikasian tersebut yaitu, 17 bentuk negasi -nu, 17 bentuk negasi- zu (-ni), dan 16 bentuk negasi -mai. Bentuk-bentuk tersebut dibagi lagi berdasarkan penggunaan dan maknanya pada sebuah kalimat. Bentuk negasi -nu merupakan morfem terikat karena tidak bisa berdiri sendiri selalu menempel pada verba. Saat berkonjugasi dengan sebuah verba, bentuk negasi -nu akan mempengaruhi makna verba atau kalimat yang diikutinya. Bentuk negasi -zu (-ni) termasuk kedalam jodoushi (kata kerja bantu) dan merupakan morfem terikat karena tidak bisa berdiri sendiri. Bentuk negasi -zu (-ni) 
bergabung dengan verba atau adjektiva-I berperan sebagai penghubung antar klausa dan biasanya memiliki hubungan sebab akibat atau saling menerangkan. Bentuk negasi -mai termasuk kedalam jodoushi (kata kerja bantu) dan merupakan morfem terikat karena tidak bisa berdiri sendiri dan dapat berkonjugasi dengan verba, adjektiva dan nomina.

\section{Hasil dan Pembahasan}

Berikut adalah hasil analisis tentang pembentukan negasi verba dialek Osaka dalam novel Hibana karya Matayoshi Naoki.

\subsection{Pembetukan Negasi Verba Dialek Osaka}

Bagian ini menguraikan hasil analisis pembentukan negasi verba dialek Osaka yang meliputi bentuk negasi yang ditandai dengan penggunaan verba bantu -hen (setara dengan nai pada bahasa Jepang standar), dan verba bantu -hin (setara dengan -nai pada bahasa Jepang standar) dalam novel Hibana karya Matayoshi Naoki.

\subsubsection{Negasi Verba -Hen}

Negasi verba yang diikuti oleh sufiks -hen dibentuk sesuai dengan jenis kosakata kerja dalam bahasa Jepang yaitu godandoushi dan ichidan doushi. Dalam bahasa Jepang kata kerja golongan I disebut godandoushi, yaitu kata kerja yang berakhiran suara $\{-u\},\{-t s u\}$, $\{-r u\},\{-m u\},\{-n u\},\{-b u\},\{-k u\},\{-g u\},\{-s u\}$. Sedangkan kata kerja golongan II disebut ichidandoushi. Ichidandoushi dibagi menjadi dua yaitu kami ichidan doushi yang merupakan kata kerja yang berakhiran $\{$-iru\}, serta shimo ichidan doushi yang merupakan kata kerja berakhiran suara $\{$-eru $\}$. Pada pola negasi verba -hen hanya dapat digunakan untuk shimo ichidan doushi saja. Berikut adalah data mengenai pembentukan negasi verba -hen yang terdapat dalam novel Hibana karya Matayoshi Naoki.

1.そんなん、ほんまにやっても誰も笑わへんから。 Sonnan, honma ni yattemo daremo warawahenkara.

'Seserius apapun dilakukan, sudah pasti tidak ada yang tertawa'.

(Hibana, 2015:18)

Verba warau 'tertawa' secara morfologis terdiri dari dua morfem, yaitu \{wara\} sebagai gokan atau morfem pangkalnya, dan $\{-u\}$ sebagai gobi atau penanda akhir. Perubahan negasi terjadi pada gobi $\{-u\}$ yang memunculkan fonem /w/ dan /a/ sebelum bentuk negasi -hen. Pola perubahan bentuk negasi dapat diurai seperti di bawah ini : 


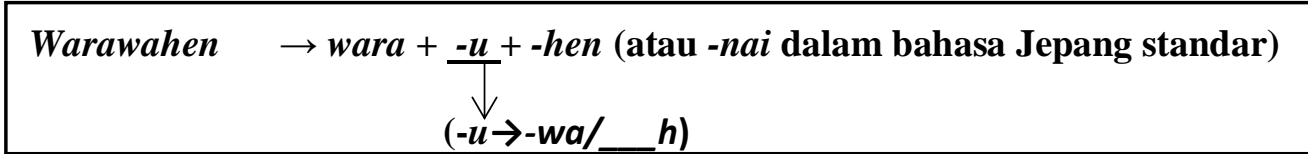

2. そんなお前にしか作れへん笑いが絶対あるんやで。 Sonna omae ni shika tsukurehen warai ga zettai arun yade.

'sudah pasti tidak ada yang bisa membuat lelucon selain dirimu'.

(Hibana, 2015:22)

Verba tsukureru 'dapat membuat' secara morfologis terdiri dari dua morfem, yaitu \{tsukur\} sebagai gokan atau morfem pangkalnya, dan $\{$-eru $\}$ sebagai gobi. Perubahan negasi terjadi pada gobi \{-eru\} yang memunculkan fonem /e/ sebelum bentuk negasi -hen. Pola perubahan bentuk negasi dapat diurai seperti di bawah ini :

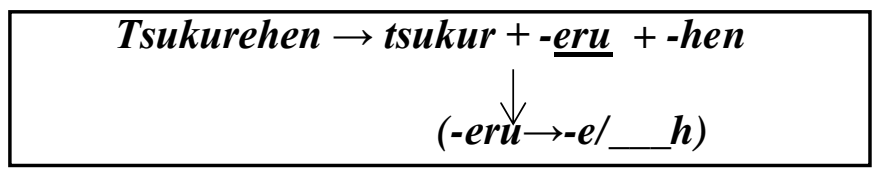

3. タバコ吸わへんって言ってたんやなかったのか。

Tabako suwahentte ittetan yana kata no ka.

'Bukannya kamu berkata tidak merokok ya'.

(Hibana, 2015:75)

Verba suи 'menghisap' secara morfologis terdiri dari dua morfem, yaitu $\{s u\}$ sebagai gokan atau morfem pangkalnya, dan $\{-u\}$ sebagai gobi. Perubahan negasi terjadi pada gobi $\{-u\}$ yang memunculkan fonem /w/ dan /a/ sebelum bentuk negasi -hen. Pola perubahan bentuk negasi dapat diurai seperti di bawah ini :

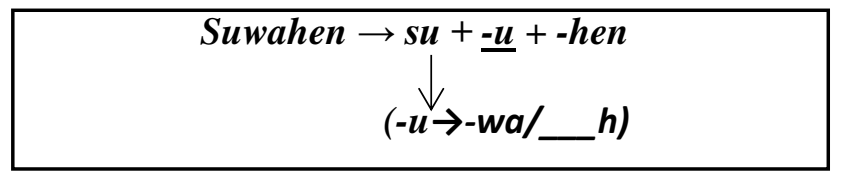

4. そういうの断れへんやろ?

Souiu no kotowarehen yoro?

'Sudah pasti kamu tidak bisa menolak hal seperti ini bukan?'.

(Hibana, 2015:83)

Verba kotowareru 'dapat menolak' secara morfologis terdiri dari dua morfem, yaitu \{kotowar\} sebagai gokan atau morfem pangkalnya, dan $\{$-eru\} sebagai gobi. Perubahan negasi terjadi pada gobi \{-eru\} yang memunculkan fonem /e/ sebelum bentuk negasi -hen. Pola perubahan bentuk negasi dapat diurai seperti di bawah ini : 


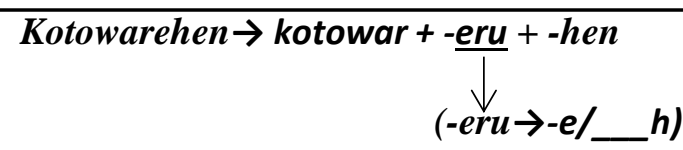

\subsubsection{Negasi Verba -Hin}

Negasi verba yang diikuti oleh sufiks - hin hanya dapat digunakan dalam kosakata kerja dalam bahasa Jepang golongan II. Dalam bahasa Jepang kata kerja golongan II disebut ichidan doushi, yaitu kata kerja yang suara akhirnya berakhiran \{-iru\} dan I. Ichidandoushi dibagi menjadi dua yaitu kami ichidan doushi yang merupakan kata kerja yang suara akhirnya berakhiran $\{$-iru\}, serta shimo ichidan doushi yang merupakan kata kerja yang suara akhirnya berakhiran $\{$-eru\}. Pada pola negasi verba -hin hanya dapat digunakan untuk kami ichidan doushi saja. Berikut adalah data mengenai negasi verba -hin yang diurai asal pembentukannya.

5. 漫才は一人では出来ひんねん。 Manzai wa hitori de wa dekihin nen.

'Manzai itu tidak bisa dipraktek sendiri'.

(Hibana, 2015:133)

Verba dekiru 'bisa' secara morfologis terdiri dari dua morfem, yaitu \{deki\} sebagai gokan atau morfem pangkalnya, dan $\{-r u\}$ sebagai gobi. Perubahan terjadi pada gobi $\{-r u\}$ yang dihilangkan, kemudian membentuk negasi -hin. Pola perubahan bentuk negasi dapat diurai seperti di bawah ini :

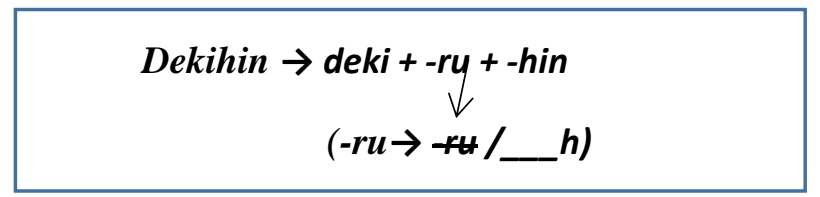

6.ほんまやな、絶対落ちひんな。

Honma yana, zettai ochihinna.

'Benar ya, tidak jatuhkan ya'.

(Hibana, 2015:126)

Verba ochiru 'jatuh' secara morfologis terdiri dari dua morfem, yaitu \{ochi\} sebagai gokan atau morfem pangkalnya, dan $\{-r u\}$ sebagai gobi. Perubahan terjadi pada gobi $\{-r u\}$ yang dihilangkan, kemudian membentuk negasi -hin. Pola perubahan bentuk negasi dapat diurai seperti di bawah ini : 


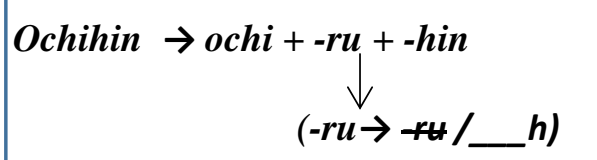

7.すまんな。お金足りひんかったってほんまか。 Sumanna. Okane tarihin kattatte honma ka.

'Maaf ya. Apa benar uang nya kurang'.

(Hibana, 2015:77)

Verba tariru 'cukup' secara morfologis terdiri dari dua morfem, yaitu \{tari\} sebagai gokan atau morfem pangkalnya, dan $\{-r u\}$ sebagai gobi. Perubahan terjadi pada gobi $\{-r u\}$ yang dihilangkan, kemudian membentuk negasi -hin. Pola perubahan bentuk negasi dapat diurai seperti di bawah ini :

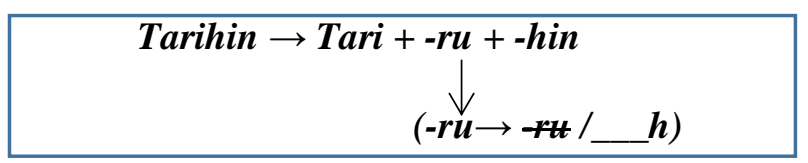

\subsection{Makna Negasi Verba Dialek}

\subsubsection{Makna Negasi Verba Dialek Osaka}

Dalam bahasa Jepang tindak tutur ilokusi disebut hatsuwanaikoui. Tindak tutur ilokusi adalah tindak tutur yang bila penutur mengatakan X maka ia menegaskan Y. Dapat dipahami bahwa melalui tindak tutur dapat terjadi tindakan yang mengandung fungsi terima kasih, permintaan, pelaporan, perjanjian, pertanyaan, pemberkatan, perintah, dan lain sebagainya.

(Austin dalam Fujibayashi 2001:5). Dalam penelitian ini ditemukan beberapa makna negasi verba dialek Osaka dalam novel Hibana karya Matayoshi Naoki yang diklasifikan kedalam tindak tutur ilokusi. Berikut adalah data-data tersebut.

\subsubsection{Assertives (tindak tutur asertif)}

Assertives atau tindak tutur asertif disebut enjutsukousai dalam bahasa Jepang (Searle dalam Yamaoka, 2006: 140). Tindak tutur asertif merupakan tindak tutur yang digunakan penutur untuk menyampaikan suatu keadaan kepada mitra tutur. Tindak tutur asertif mengikat kebenaran yang diujarkan. Berikut adalah contoh data tindak tutur asertif. 
8. 徳永 ：当たらないっすね。暇っすね。

山下：もう一千も残ってないっすよ。大赤字ですわ。

徳永：まあ、こんな日もあるって。俺の金まだ残ってるか

ら貸したるよ。

山下：おふくろはよく人から金を借りるなといってはった な。なあ、貸すのじゃなくて、その残った金くれへ んか?

徳永：アホか。貸すのは貸すんや。神谷さんはどうするん ですか。

神谷 : なかなかあたりでえへんな、まさか騙されてる分 けちやうやろうな。

徳永：考えすぎとちやいますか。ただ単に神谷さんが負け すぎなんですよ。

Tokunaga : Ataranaissune. Himassune.

Yamashita : :Mou issen mo nokottenaissuyo. Ooakajidesuwa.

Tokunaga : : Maa, konna hi mo arutte. Ore no kane mada nokotterukara kashitaruyo.

Yamashita : Ofukuro wa yoku hito kara kane wo kariruna to ittehattana. Naa, kasu no jyanakute, sono kane kurehenka?

Tokunaga : Ahoka, kasu no wa kasunya. Kamiyasan wa dousurunsuka?.

Kamiya : Naka naka Atari ga deehenna, masaka damasareteru wakechauyarouna.

Tokunaga : Kangaesugitochaimasuka. Tadatan ni Kamiyasan ga makesuginandesuyo.

Tokunaga : Tidak dapat ya. Membosankan ya.

Yamashita : Sudah tidak tersisa sepeserpun. Rugi besar nih.

Tokunaga : Hari seperti ini pun ada kok. Uang ku masih tersisa, akan ku pinjamkan kepada mu.

Yamashita : Ibuku sering berkata jangan meminjam uang dari orang lain. Bisakah kamu bukan meminjamkan tapi berikan saja kepadaku.

Tokunaga : Dasar bodoh. Kalau meminjamkan ya meminjamkan. Kamiya, dirimu bagaimana?

Kamiya : Cukup sulit untuk mendapatkannya ya, apa mungkin kita di tipu ya.

Tokunaga : Dirimu terlalu berpikir lebih. Itu hanya karena dirimu terlalu banyak kalah Kamiya.

(Hibana, 2015: 17)

Tuturan pada data (8) merupakan tuturan antara Kamiya (penutur), Tokunaga dan Yamashita (mitra tutur) yang terjadi di tempat bermain lotre. Kata deehen pada kalimat diatas adalah negasi verba dialek Osaka yang memiliki arti tidak keluar. Tuturan naka naka atari deehen na, masaka damasare teru wake chau yarou na pada data (8) merupakan tindak 
tutur asertif. Ungkapan 'cukup sulit untuk mendapatkannya ya, apa mungkin kita di tipu ya' dikatakan penutur untuk menutupi fakta jika uang yang dibawanya sudah hampir habis. Data (8) di kategorikan dalam tindak tutur asertif yang mana pada tuturan yang di ucapkan oleh tokoh Kamiya terkandung tuturan pembualan karena ia berusaha menutupi fakta bahwa ia hampir kehabisan uangnya. Ini dapat dilihat dari kata naka naka dalam kalimat tuturan tersebut. Tomoko (2016:55) mengatakan bahwa pola naka naka jika digunakan dalam kalimat negatif menunjukkan situasi yang tidak mudah atau tidak dapat dilakukan sebagaimana yang diharapkan. Hal ini sesuai dengan teori tindak tutur ilokusi asertif milik Searle (dalam Yamaoka, 2006:140).

\subsubsection{Directives (tindak tutur direktif)}

Directives atau tindak tutur direktif dalam bahasa Jepang disebut dengan shidoukoui (Searle dalam Yamaoka, 2006: 140). Tindak tutur direktif adalah tindak tutur yang digunakan penutur agar mitra tuturnya melakukan sesuatu yang diharapkan oleh si penutur. Berikut adalah contoh data tindak tutur direktif.

9. 神谷：まあ、俺も真樹に好きな人ができたんなら文句ない

けどな。年齢的なこともあるし、俺が何とかした かったけど、間に合わんかったな。ここでごちゃ ごちやいうのも狡いしな。ほかの選択肢もなかっ たんやろうなと思う。

徳永：荷物全部出すんですか

神谷：いやまだ家が決まってへんからそれは無理やねんけ

ど。明日、劇場の出番あるから漫才衣装と着替え だけ取りたいねん。一つ問題があってな、実はそ の男がもう家におんねん

大林：そうなんですか

神谷：俺のこと居候と説明してるらしいねんけど、そん な部屋に気まずくて一人で行かれへんやろ。

徳永：そうですね

Kamiya : : Maa, oremo Maki ni suki na hito ga dekitannara monkunai kedo na. Nenreitekina koto mo arushi, orega nantoka shitakatta kedo, maniawankattana. Kokode gocha gocha ittemokosuishina. Hoka no sentakushi mo nakattan yarouna to omou.

Tokunaga $\quad$ : Nimotsuzenbu dasundesuka.

Kamiya $\quad$ : Iya mada ie ga kimattehenkara sore wa muriyanenkedo. Ashita, gekijyou no deban arukara manzaiishou to kigae dake toritainen. Hitotsumondai ga attena, jitsu wa sono otokoga mou ie ni onnen. 


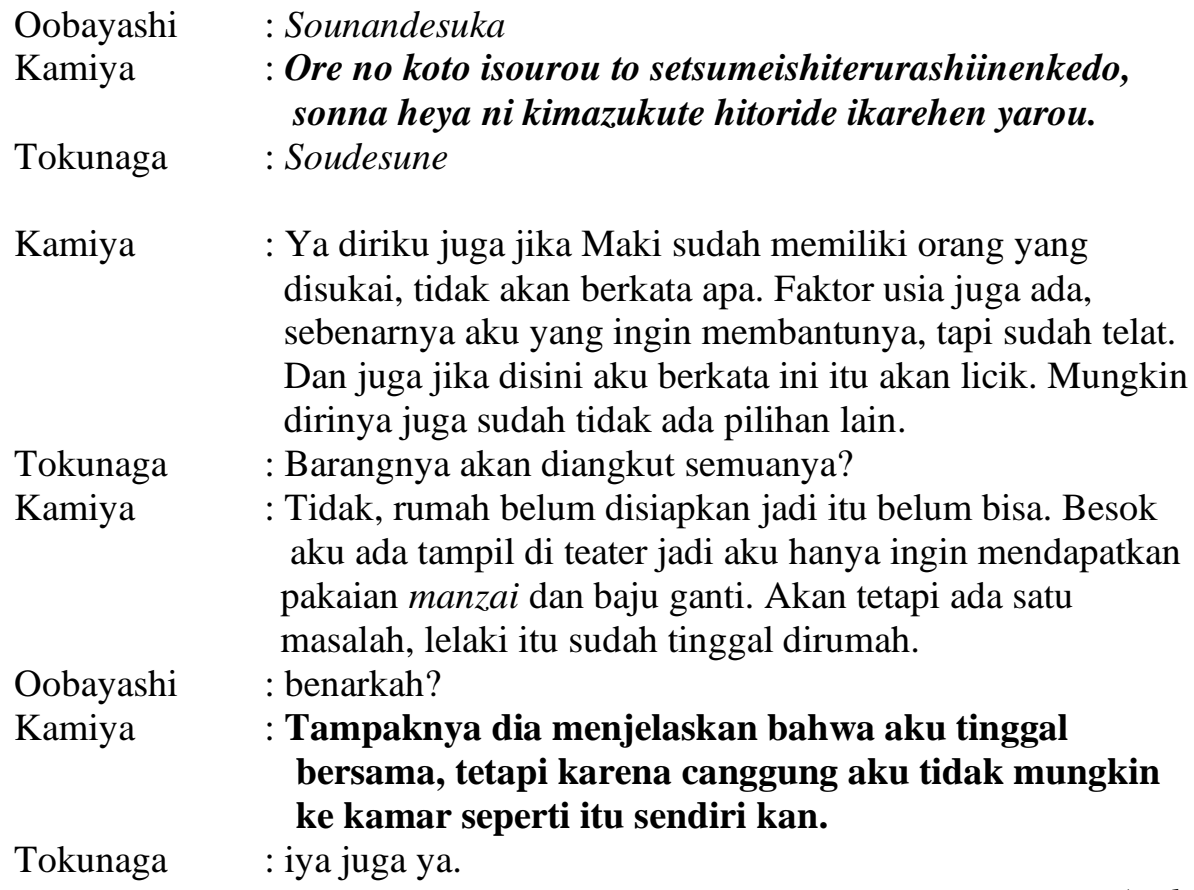

(Hibana, 2015: 86)

Tuturan pada data (9) merupakan tuturan antara Kamiya (penutur) dengan Tokunaga dan Oobayashi (mitra tutur) yang terjadi di apartement Tokunaga. Pada saat itu Kamiya berdiskusi mengenai perpindahan rumah. Kata ikarehen pada kalimat diatas merupakan negasi verba dialek Osaka yang berarti tidak dapat pergi. Tuturan ore no koto isourou to setsumeishiterurashiinenkedo, sonna heya ni kimazukute hitoride ikarehen yarou 'tampaknya dia menjelaskan bahwa aku tinggal bersama, tetapi karena canggung aku tidak mungkin ke kamar seperti itu sendiri kan'. Tokoh Kamiya memohon pada tokoh Tokunaga dan kawan-kawan untuk mengantarnya ke rumah dan mengangkut semua barang miliknya. Data (8) merupakan tindak tutur direktif permohonan. Data ini dikategorikan dalam tindak tutur direktif yang mana pada tuturan yang di ucapkan oleh tokoh Kamiya terkandung tuturan permohonan dimana dia tidak ingin pergi sendirian ke rumah yang sekarang sudah ditinggali Maki dan kekasihnya. Hal ini sesuai dengan teori tindak tutur ilokusi milik Searle (dalam Yamaoka, 2006: 140).

\subsubsection{Expressives (Tindak Tutur Ekpresif)}

Expressives atau tindak tutur ekpresif disebut hyoushutsukoui dalam bahasa Jepang (Searle dalam Yamaoka, 2006: 140). Tindak tutur ekspresif adalah tindak tutur yang digunakan untuk mengutarakan sikap psikologis penutur terhadap keadaan yang tersirat 
dalam ilokusi. Tindak tutur ini untuk mengekspresikan perasaan dan sikap penuturnya. Berikut adalah contoh data tindak tutur direktif.

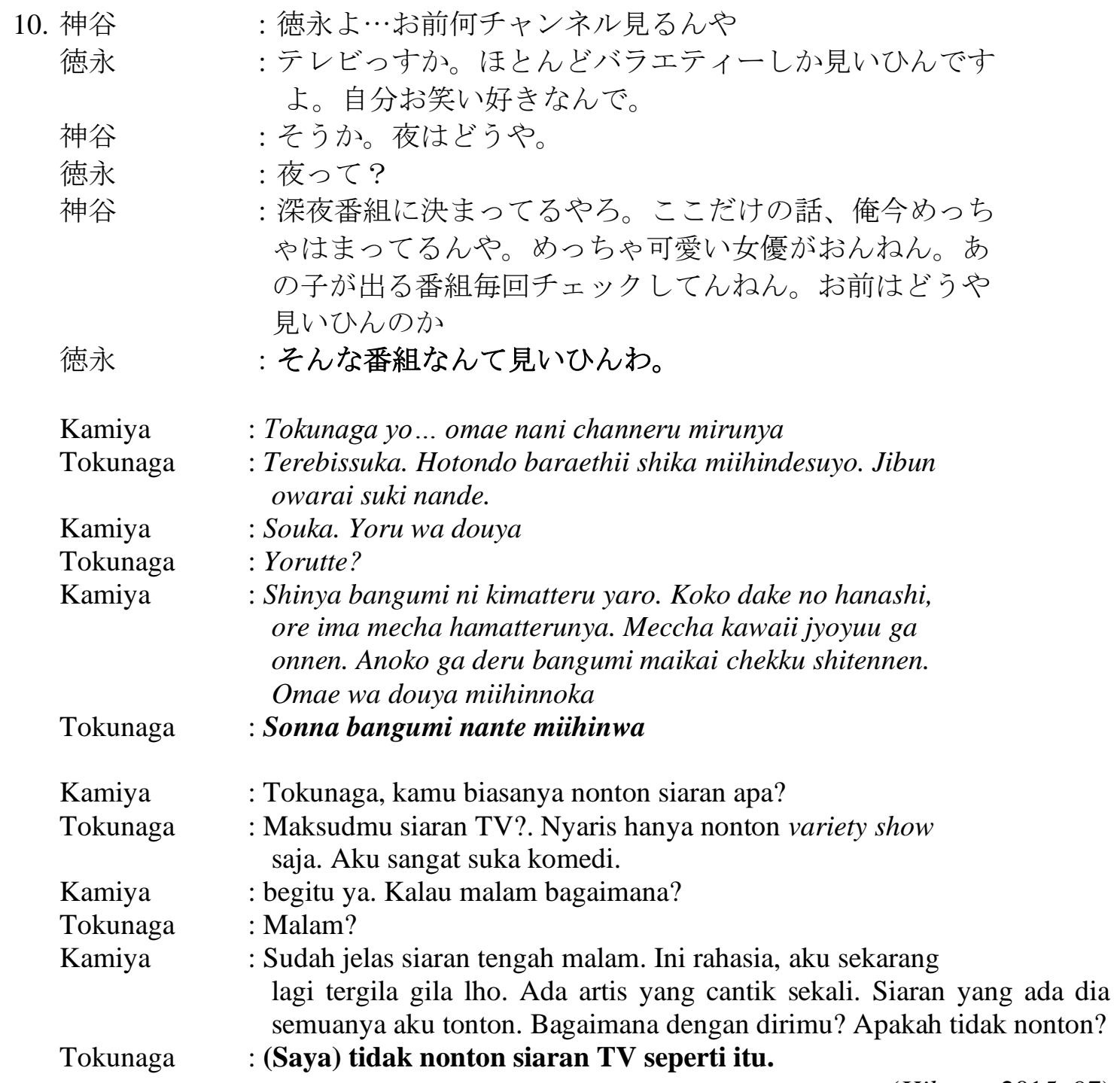

(Hibana, 2015: 97)

Tuturan pada data (10) merupakan tuturan antara Tokunaga (penutur) dan Kamiya (mitra tutur) yang terjadi di rumah Kamiya. Pada saat itu Kamiya dan Tokunaga sedang menonton drama. Kata miihin pada percakapan di atas merupakan negasi verba dialek Osaka yang berarti tidak melihat. Tuturan sonna bangumi nante miihinwa pada data (10) merupakan tindak tutur ekspresif. Data (10) di kategorikan dalam tindak tutur ekspresif yang mana pada tuturan yang di ucapkan oleh tokoh Tokunaga terkandung tuturan menentang. Hal ini dapat dilihat dari ucapan Tokunaga yang tidak setuju dengan perkataan Kamiya yang mengatakan bahwa siaran tengah malam itu sangat bagus hingga membuatnya tergila-gila. Tokunaga bahkan merendahkan siaran TV tengah malam yang ditonton oleh Kamiya dengan 
berujar 'saya tidak menonton siaran TV seperti itu' dengan sedikit ketus. Hal ini dapat dilihat pula dengan penggunaan kata nante dalam tuturan data (10). Iori (2001:367) mengatakan bahwa ungkapan nante digunakan untuk menegaskan suatu unsur berupa penilaian dari pembicara terhadap suatu hal. Makna yang terdapat dalam partikel nante antara lain menunjukkan hal yang wajar, menunjukkan sesuatu yang tidak mungkin dan menegaskan sesuatu yang bernilai rendah. Ini sesuai dengan teori tindak tutur ilokusi Searle (dalam Yamaoka, 2006: 140) yaitu tindak tutur ekspresif menentang.

\section{Simpulan dan Saran}

Berdasarkan hasil analisis mengenai dapat disimpulkan bahwa negasi verba yang diikuti oleh sufiks -hen dibentuk sesuai dengan jenis kosakata kerja dalam bahasa Jepang yaitu godandoushi dan ichidan doushi. Dalam bahasa Jepang kata kerja golongan I disebut godandoushi, yaitu kata kerja yang berakhiran suara $-u,-t s u,-r u,-m u,-n u,-b u,-k u,-g u,-s u$. Sedangkan kata kerja golongan II disebut ichidandoushi. Ichidandoushi dibagi menjadi dua yaitu kami ichidan doushi yang merupakan kata kerja berakhiran -iru, serta shimo ichidan doushi yang merupakan kata kerja berakhiran suara -eru. Pada pola negasi verba hen hanya dapat digunakan untuk shimo ichidan doushi saja. Ditemukan enam data yang mengandung unsur negasi verba -hen yaitu warawahen, tsukurehen, suwahen, kotowarehen, ikehen, dan tsukawasehen.

Selain negasi verba -hen ditemukan pula negasi verba yang diikuti oleh sufiks -hin. Negasi verba -hin hanya dapat digunakan dalam kosakata kerja dalam bahasa Jepang golongan II. Dalam bahasa Jepang kata kerja golongan II disebut ichidan doushi, yaitu kata kerja yang berakhiran suara -iru dan -eru. Ichidandoushi dibagi menjadi dua yaitu kami ichidan doushi yang merupakan kata kerja berakhiran -iru, serta shimo ichidan doushi yang merupakan kata kerja berakhiran suara - eru. Pada pola negasi verba -hin hanya dapat digunakan untuk kami ichidan doushi saja. Ditemukan empat data yang mengandung unsur negasi verba -hin yaitu dekihin, ochihin, tarihin, dan kiihin.

Pada rumusan masalah kedua, ditemukan 13 bentuk tindak tutur ilokusi yang menggunakan negasi verba dialek Osaka dalam novel Hibana karya Matayoshi Naoki. Dalam pembagiannya ditemukan tiga data yang mengandung unsur tindak tutur asertif, yaitu satu data tindak tutur asertif yang mengandung tuturan pembualan, dan dua data tindak tutur asertif yang mengandung tuturan berspekulasi. Ditemukan pula dua data tindak tutur direktif yang mengandung tuturan pemberian nasehat dan tuturan permohonan, serta delapan data 
yang mengandung unsur tindak tutur ekspresif yaitu satu data tindak tutur ekspresif yang mengandung tuturan menetang, satu data tindak tutur ekspresif yang mengandung tuturan komplain, satu data tindak tutur ekspresif yang mengandung tuturan kritik, lima data tindak tutur ekspresif yang mengandung tuturan mengeluh.

\section{Daftar Pustaka}

Alwi, Hasan dkk. 2005. Kamus Besar Bahasa Indonesia. Jakarta: Departemen Pendidikan Nasional Balai Pustaka.

Fujibayashi. (2001). Hatsuwakoui no Goyouronteki Kenkyuu. [pdf]. http://www2.dokkyo.ac.jp/ esemi008/papers/fujibayashi.pdf

Chaer, Abdul. 2008. Morfologi Bahasa Indonesia (Pendekatan dan Proses). Jakarta: rineka Cipta.

Iori, Isao. (2001). Atarashii Nihongo Gaku Nyuumon, Kotoba no Shikumi wo Kangaeru. Japan: 3 A Corporation.

Natsuko, Tsujimura. 1999. An Introduction to Japanese Linguistics. USA: Blackwell Publishers.

Nurhasanah, Sulastri. 2012. Analisis Settougo fu-, mu-, hi- dan mi- dalam Bahasa Jepang. Jawa tengah: Universitas Negeri Semarang.

Kridalaksana, Harimurti. 2001. Kamus Linguistik. Jakarta: Gramedia Pustaka Utama.

Purba, Julia Kiranta. 2008. Analisis Bentuk Negasi ぬ,ず(に)dan まい Dalam Kalimat Bahasa Jepang (Kajian Morfosintaksis dan Semantik). Bandung: Universitas Kristen Maranatha.

Rohmah, Masyitoh Mawaddah. 2017. Analisis Tindak Tutur Dalam Komik Tokyo Ghoul: Re Karya Ishida Sui. Sumatera: Universitas Sumatera Utara.

Sudjianto dan Ahmad Dahidi. 2007. Pengantar Linguistik Bahasa Jepang. Jakarta: Kesiantblanc.

Tomoko, Morimoto. 2016. Nihongo Nouryokushiken Sougou Tekisuto N4. Japan: J research.

Wedayanti, N. P. L. 2015. Produktivitas kata Harassment Berkomposisi Dalam Bahasa Jepang. PRASI, 10(19).

Wedayanti, N. P. L. 2016. Morphological Process of Suffix-Shi In Japanese

Yamaoka, Masaki. 2006. Hatsuwakoui to Hatsuwa Kinou no Hikaku. International Journal of Pragmatics Vol. XVI: Pragmatics Association of Japan. 7. 